\title{
Incidence and effects of four parasites in natural populations of bumble bees in Switzerland
}

\author{
JA Shykoff *, P Schmid-Hempel \\ Zoologisches Institut der Universität Basel, Rheinsprung 9, CH-4051 Basel, Switzerland
}

(Received 16 August 1990; accepted 9 January 1991)

\begin{abstract}
Summary - Field caught bumble bee (Bombus Latreille and Psithyrus Lepeletier) workers, males and queens were examined for the presence of 4 parasites. High prevalence of parasitization by conopid flies $(20.2 \%)$ and the trypanosome Crithidia bombi $(35.7 \%)$, moderate to low prevalence by the microsporidian Nosema bombi $(9.0 \%)$ and the mite Bombacarus buchneri (3.6\%) were found. Infestations by the 4 parasites were independent of one another but significant differences were found for bumble bee species and sex. Workers parasitized by $C$ bombi were significantly less likely to forage for pollen and had developed ovaries in significantly more cases than did uninfested workers. Spring queens of $B$ terrestris and $B$ lucorum had lower prevalence of infestation by $C$ bombi than was found in workers the previous summer.
\end{abstract}

Bombus / Psithyrus / parasitism / Crithidia / Nosema / Bombacarus / Conopidae

\section{INTRODUCTION}

Bumble bees (Bombus Latreille and Psithyrus Lepeletier), economically and ecologically important pollinators of many temperate plant species (Heinrich, 1979), harbour a number of parasites and parasitoids (Alford, 1975). Field collections in northwestern Switzerland reveal high prevalence of conopid fly eggs and larvae (Diptera, Conopidae) (Schmid-Hempel and Schmid-Hempel, 1988, 1989; SchmidHempel et al, 1990). Nest-seeking spring queens often contain Sphaerularia bombi (Nematoda, Tylenchoidea, Allantonematidae) and occasionally Syntretus splendid- us (Hymenoptera, Braconidae) infestations (Schmid-Hempel et al, 1990). Other bumble bee parasites include the tracheal mite, Bombacarus buchneri (Acarina, Podapolipodidae) (Stammer, 1951), and the protozoans Nosema bombi (Microsporidia, Nosematidae) (Showers et al, 1967; de Jonghe, 1986; Fisher and Pomeroy, 1989) and Crithidia bombi (Trypanosomatidae, Zoomastigophorea) (Lipa and Triggiani, 1980; Gorbunov, 1987).

Parasites can have negative effects on the individual and the colony. Bumble bees infested with conopids have shorter lifespans than uninfested ones (SchmidHempel and Schmid-Hempel, 1988), re-

\footnotetext{
* Correspondence and reprints: Institut voor Oecologisch Onderzoek, Boterhoeksestraat 22, 6666 GA Heteren, The Netherlands
} 
sulting in lower return per unit investment for the colony and reduced worker populations. Parasitized workers prefer different flowers than do unparasitized workers, which may alter their effectiveness as pollinators and competitors (Schmid-Hempel and Schmid-Hempel, 1990). Qu!eens infested with the braconid $S$ splendidus or the nematode $S$ bombi fail to found nests. Little is known about the effects of protozoa on bumble bees. In honey bees, $N$ apis causes higher winter losses (Jeffree and Allen, 1956) and reduced honey yields in infested colonies, infested queens are more often superseded (Farrar, 1947), and infested workers show reduced hoarding behaviour (Rinderer and Elliott, 1977). Bumble bees cross-infected with $N$ apis show reduced activity (Showers et al, 1967), though Fisher and Pomeroy (1989) found no effect of $N$ bombi on either colony performance or queen success. Crithidia spp are pathogens of other insects (Clark et al, 1964), but little is known about their effects on bees (Fyg, 1954; Langridge and Mcghee, 1967). Because parasites could affect bumble bee population dynamics, behaviour and ecology, more information is needed on parasites in natural bumble bee populations.

To date, few data are available on the distribution, abundance, and ecological effects of parasites in natural populations of their hosts. Here we report the results of field surveys in northwestern Switzerland, conducted to assess the distribution, abundance and impact of a number of parasites in natural populations of bumble bees.

\section{MATERIALS AND METHODS}

Eight samples, each of $\approx 50$ bumble bees, were collected at 2 field sites in the vicinity of Basel, Switzerland in early and late July and August, 1988. In the laboratory, bees were checked for presence of pollen in the corbiculae, freeze- killed, dissected, and examined for the presence of various parasites. Each individual was scored for the presence of the 2 protozoans, Crithidia bombi and Nosema bombi, eggs or larvae of conopid flies and tracheal mites, Bombacarus buchneri. In addition the state of development of the ovaries was scored. Fisher's exact tests (for $2 \times 2$ contingency tables) or $G$ log-likelihood tests (for higher order tables) were used to test whether infestation prevalence was independent of site, host species and sex, if presence of the various parasites was independent of one another and to determine the relationship between infestation, host foraging behaviour (pollen foraging or not) and host ovarian development (Zar, 1984; SAS Institute, 1985). All probability levels reported are two-tailed.

In spring 1989 , foraging and nest-searching queens of Bombus terrestris $L$ and Bombus lucorum $\mathrm{L}$ were collected. The queens were placed in the laboratory in wooden boxes containing nest material (upholsterer's cotton), and given sugar/honey solution and pollen (for methods on bumble bee rearing, see Plowright and Jay, 1966). Fresh faeces were obtained from all queens whenever possible and examined for $N$ bombi spores and cells of $C$ bombi at $400 X$ magnification. Queens which died or failed to commence egg-laying within $3 \mathrm{wk}$ were examined for parasites, and the 3 largest terminal oocytes were measured using an eyepiece micrometer in a dissecting microscope. Tests of association as above were performed to investigate whether nest-founding success was independent of infestation by $N$ bombi or $C$ bombi. Average length of the 3 largest oocytes was compared between individuals infected or uninfected with $N$ bombi and $C$ bombi using a t-test. In addition, prevalence of infestation by $N$ bombi and $C$ bombi in spring queens was compared with that in workers from the summer before using a G log-likelihood test.

\section{RESULTS}

A total of 446 bumble bees ( 313 workers and 133 males) were investigated for parasites in July and August 1988. Representatives of 9 species were found, the commonest being $B$ pascuorum Scop, $B$ lapidarius $L, B$ terrestris and $B$ lucorum. 
Workers of the last 2 species are difficult to distinguish from one another so they are combined in the analyses, as are the remaining rare species in all except for the analysis of tracheal mite infestation by species. The 2 field sites were consistent in patterns of parasite prevalence, so sites were also combined in the following analyses.

Altogether $20.2 \%$ of the bumble bees were infested with conopids, $35.7 \%$ with $C$ bombi, $9.0 \%$ with $N$ bombi and $3.6 \%$ with
Bombacarus buchneri. Parasitization differed by host species for all parasites and by host sex for conopids, $\mathrm{C}$ bombi, $\mathrm{N}$ bombi (table 1). Conopid parasitization was more common than expected in $B$ pascuorum $(\mathrm{G}=18.1$, df $=3, P<0.0001)$. B lapidarius and combined $B$ terrestris/lucorum showed higher than expected prevalence of $C$ bombi infestation $(\mathrm{G}=134.251$, $\mathrm{df}=$ $3, P<0.0001)$. Combined $B$ terrestris/ lucorum had higher than expected $N$ bombi infestation $(\mathrm{G}=30.463$, df $=3, P<$

Table I. Parasitization of bumble bee species in northwestern Switzerland in the summer of 1988. The table shows the total number of individuals of each species and sex examined, and the number and percent of those which contained parasites. The parasites represented here include conopoid flies (Sicus sp and Physocephala sp), the trypanosome Crithidia bombi, the microsporidian Nosema bombi, and the tracheal mite Bombacarus buchneri. Some bees contained more than one parasite species.

\begin{tabular}{|c|c|c|c|c|c|}
\hline \multirow{2}{*}{$\begin{array}{l}\text { Species } \\
\text { sex }\end{array}$} & \multirow{2}{*}{ Total examined } & \multicolumn{4}{|c|}{ No of individuals parasitized with (\%) } \\
\hline & & Conopoids & C bombi & $\mathrm{N}$ bombi & B buchneri \\
\hline \multicolumn{6}{|c|}{$B$ terrestris/lucorum } \\
\hline Workers & 61 & $14(22.9)$ & $49(80.3)$ & $9(14.8)$ & 0 \\
\hline Males & 24 & $4(16.7)$ & $13(54.2)$ & $12(50.0)$ & 0 \\
\hline \multicolumn{6}{|c|}{ B pascuorum } \\
\hline Workers & 132 & $40(30.3)$ & $11(8.3)$ & $3(2.3)$ & $8(6.1)$ \\
\hline Males & 35 & $3(8.6)$ & 0 & $3(8.6)$ & $2(5.7)$ \\
\hline \multicolumn{6}{|l|}{ B lapidarius } \\
\hline Workers & 81 & $22(27.2)$ & $43(53.1)$ & 0 & 0 \\
\hline Males & 26 & $2(7.7)$ & $4(15.4)$ & $4(15.4)$ & 0 \\
\hline \multicolumn{6}{|l|}{ B pratorum } \\
\hline Workers & 12 & $1(8.3)$ & $7(58.3)$ & 0 & $6(50.0)$ \\
\hline Males & 6 & 0 & $1(16.7)$ & 0 & 0 \\
\hline \multicolumn{6}{|l|}{ B hortorum } \\
\hline Workers & 11 & $2(18.2)$ & $4(36.4)$ & $6(54.5)$ & 0 \\
\hline Males & 10 & $2(20.0)$ & $5(50.0)$ & $1(10.0)$ & 0 \\
\hline \multicolumn{6}{|l|}{ B hypnorum } \\
\hline Workers & 8 & 0 & $8(100)$ & $1(12.5)$ & 0 \\
\hline Males & 8 & 0 & $4(50.0)$ & $1(12.5)$ & 0 \\
\hline \multicolumn{6}{|c|}{$\begin{array}{l}\text { B humilis and } \\
B \text { sylvarum }\end{array}$} \\
\hline Workers & 6 & 0 & $2(33.3)$ & 0 & 0 \\
\hline Males & 0 & 0 & 0 & 0 & 0 \\
\hline \multicolumn{6}{|c|}{ Psithyrus spp } \\
\hline Females & 2 & 0 & 0 & 0 & 0 \\
\hline Males & 24 & 0 & $8(33.3)$ & 0 & 0 \\
\hline Total & 446 & $90(20.2)$ & $159(35.7)$ & $40(9.0)$ & $16(3.6)$ \\
\hline
\end{tabular}


$0.0001)$. The mite $B$ buchneri was only found in $B$ pascuorum and $B$ pratorum $L$ ( $\mathrm{G}=39.295, \mathrm{df}=8, P<0.0001)$. Parasitization by conopids and $C$ bombi was higher for workers than males in all species but $B$ hortorum L. While $25.2 \%$ of workers contained conopid larvae or eggs, only $8.3 \%$ of males were parasitized by conopids (Fisher's exact test, $P<0.0001$ ). $C$ bombi was found in $39.6 \%$ of workers vs $26.3 \%$ of males (Fisher's exact test, $P=$ 0.009 ), and $N$ bombi in $6.1 \%$ of workers vs $15.8 \%$ of males (Fisher's exact test, $P=$ 0.002 ). This pattern of parasitization between sexes was consistent over species, ie in all species workers were more often infested than expected with conopids and $C$ bombi, and less often than expected with $N$ bombi. No sex difference was observed for infestations of $B$ buchneri.

The distribution of infestation was independent among the 4 parasites ie, parasitization by one did not make the host more or less likely to be infested by another. A weak positive association such that double infestations were somewhat more common than expected was observed between $C$ bombi and $N$ bombi (Fisher's exact test, $P=0.057$ ).

No relationship could be determined between infestation with conopids, $N$ bombi, or Bombacarus buchneri and either pollen collecting or ovarian development. Workers infested with $C$ bombi, however, were less likely to carry pollen in their corbiculae than uninfested workers $(48.4 \%$ infested workers vs $72.6 \%$ of uninfested workers carrying pollen, all species combined, Fisher's exact test, $P<0.0001$ ). They were also more likely to have developed ovaries $(14.5 \%$ infested workers vs $4.3 \%$ uninfested workers with developed ovaries, all species combined, Fisher's exact test, $P=0.003$ ).

In spring 1989, 208 queens, $101 B$ terrestris and $107 B$ lucorum, were caught in the area of Basel. Prevalence of infestation with $C$ bombi differed in the 2 species (47.5\% for $B$ terrestris and $29.9 \%$ for $B$ lucorum, Fisher's exact test, $P=0.01$ ), while only a tendency was found with $N$ bombi (prevalence $13.5 \%$ for $B$ terrestris and $5.6 \%$ for $B$ lucorum (Fisher's exact test, $P=0.058$ ).

Nest-founding success in the laboratory was independent of infestation with either parasite in both species. Infestation, however, had a negative effect on oocyte size in queens which failed to build nests in the laboratory. Queens of $B$ lucorum infested with $N$ bombi had smaller oocytes than uninfested queens $(0.3 \mathrm{~mm}, n=6$ vs $1.1 \mathrm{~mm}$, $n=96, t=3.269$, df $=100, P=0.0015$ ). No difference was found for $B$ terrestris. $C$ bombi had a comparable effect on $B$ terrestris (infested $1.0 \mathrm{~mm}, n=38$, uninfested $1.3 \mathrm{~mm}, n=42, t=2.05, \mathrm{df}=78, P=0.04$ ) but not on $B$ lucorum.

We compared the infestation rates by $C$ bombi and $N$ bombi of spring queens with the infestation rates of $B$ terrestris and $B$ lucorum workers from the summer before in an attempt to address the question of whether parasitization affects hibernation success. We used the prevalence values for infestation of previous summer workers to generate expected values. The distribution of infestation differed markedly between summer workers and spring queens (combined species $\mathrm{G}=175.52, \mathrm{df}=1, P<$ $0.0001, B$ terrestris $\mathrm{G}=53.86, \mathrm{df}=1, P<$ $0.0001, B$ lucorum $\mathrm{G}=133.15, \mathrm{df}=1, P<$ $0.0001)$. Uninfested individuals were much more common than expected in the spring queen sample and $C$ bombi infestations were rarer than expected (table II). The weak positive association between $C$ bom$b i$ and $N$ bombi reported for summer workers was not evident in spring queens. No significant difference was found between infestation rates of $N$ bombi for summer workers and spring queens. 
Table Il. Comparison of infestation by protozoan parasites $N$ bombi and $C$ bombi in summer workers and spring queens. Numbers in parentheses represent expected values generated from the observed frequencies of parasitization in workers the previous summer.

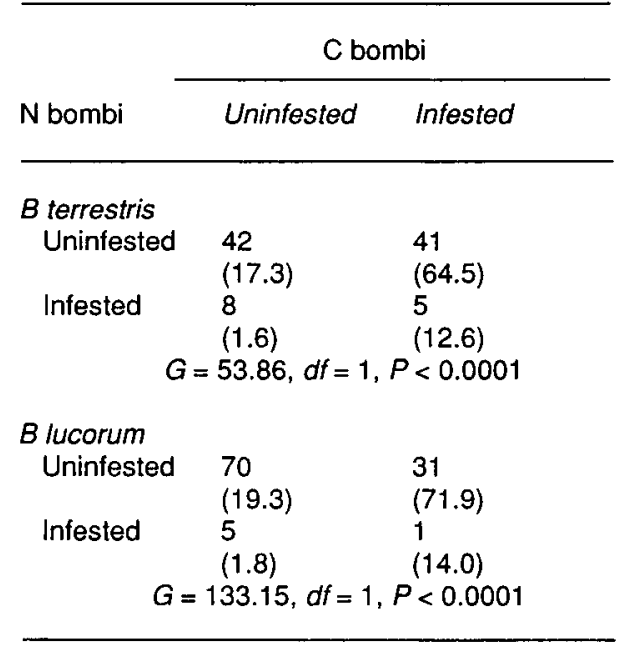

\section{DISCUSSION}

We here report the distribution and abundance of 4 different parasites of bumble bees found in natural populations in central Europe (table I). Conopid prevalence was consistent with previous reports (Cumber, 1949a; Macfarlane and Pengelly, 1974; Pouvreau, 1974; Schmid-Hempel and Schmid-Hempel, 1988; Schmid-Hempel et al, 1990). In addition, high prevalence of the trypanosome $C$ bombi was observed, particularly in workers, and moderate prevalence of the microsporidian $\mathrm{N}$ bombi, particularly in males. Differences in conopid parasitization by species and sex are known (eg, Schmid-Hempel and SchmidHempel, 1988; Schmid-Hempel et al, 1990 ) and may be due to species differences in degree of overlap between conopid and bumble bee abundances, and sex specific behaviours. As yet we have no explanation for species differences in infestation rates for $C$ bombi and $N$ bombi.

Sex-related differences in infestation are opposite for these 2 parasites, with higher prevalence of $C$ bombi in workers and of $N$ bombi in males. This suggests that patterns of transmission or susceptibility for these 2 protozoan parasites differ. Laboratory investigations of $C$ bombi and $B$ terrestris show that parasite transmission occurs readily within nests and artificially established groups of worker bumble bees (Shykoff, unpublished data; Shykoff and Schmid-Hempel, 1991a, b). Low infestation rates in males may result from males spending less time within the nest than do workers, leaving permanently within $4 \mathrm{~d}$ of eclosion (Alford, 1975). Also they do not participate in brood care, which may expose workers to infection through contact with contaminated nest material.

The factors which reduce risk of $C$ bombi transmission to males should have the same effect on $N$ bombi, but we found higher rates of $N$ bombi infestation in males than in workers. If, however, $N$ bombi reduces the activity of infested bees as shown by Showers et al (1967) for bumble bees cross-infected with $N$ apis, then parasitized invididuals may be less likely to forage than unparasitized individuals. Thus field samples would show higher infestation prevalence for males which, in contrast to workers, must leave the nest.

Evidence for pathogenic effects of Crithidia bombi is scanty. We found fewer infested workers than uninfested workers bearing pollen, and more infested workers than uninfested workers with developed ovaries. Ovarian development is a function of age (Röseler, 1987) and dominance rank (van Doorn, 1989) in bumble bees. Observations on $C$ bombi infested nests of $B$ terrestris have shown that older workers are more likely to be infested (Shykoff and 
Schmid-Hempel, 1991b). Bumble bee foragers caught in the field represent a mixture of different aged individuals (Heinrich, 1979), therefore the relationship between developed ovaries and infestation with $C$ bombi may result from a correlation of both of these factors with age. Age related patterns of infestation cannot explain the difference in pollen foraging, however, because division of labour in bumble bees does not appear to be age determined. Bumble bees can be effective pollinators without pollen foraging, but since workers infested with $C$ bombi tended not to gather pollen, they may frequent different plant species or visit flowers differently (Galen and Plowright, 1985) than uninfested workers. Further work is planned to investigate whether parasitization with $C$ bombi thus alters competitive interactions within bumble bee communities.

Infestations of $C$ bombi and $N$ bombi were found in spring queens of both $B$ terrestris and $B$ lucorum but the prevalence of $C$ bombi infestations was significantly lower than that found in workers the previous summer (table II). To investigate the dynamics of this host parasite system one should ideally compare prevalence values for young queens in summer before they enter hibernation and spring queens emerging from hibernation. Young bumble bee queens in this region are seldom seen, presumably leaving the parental nest only for the mating flight and to find an overwintering site. This enables them largely to avoid parasitization by conopids which are abundant when colonies make reproductives (Schmid-Hempel et al, 1990). Since samples of young queens were not sufficient for meaningful comparisons, we considered that infestation rates for workers should be representative of infestation rates for queens produced at the same time. Young queens remain in the nest for $5 \mathrm{~d}$ on average before their mating flight (Alford, 1975) and feed heavily on honey and pollen stores to build up fat bodies (Cumber, 1949b). After mating they often return to the parental nest (Cumber, 1953), and stay there until leaving to find a suitable hibernation site. While in the nest they participate in some brood care and are thus exposed to the same risks of transmission as are the workers. Therefore, the significant lower prevalence of $C$ bombi infestation in spring queens than previous summer workers could indicate either that this parasite reduces hibernation sucess or that some overwintering queens are able to overcome their infestations.

\section{ACKNOWLEDGMENTS}

Financial support was provided by Swiss NSF grants (Nos 3.017-0.87 and 31-25692.88) to $P$ SH.C Müller, and two anonymous reviewers provided constructive criticism on previous drafts of this manuscript.

Résumé - Présence et action de quatre parasites dans des populations naturelles de bourdons en Suisse. Nous avons étudié l'abondance et la distribution de 4 parasites naturels des bourdons (Bombus Latreille et Psithyrus Lepeletier). Sur 446 bourdons (313 ouvrières et 133 mâles) capturés sur des fleurs en juillet et août 1988, 20,2\% étaient parasités par des conopidés (Diptera, Conopidae), 35,7\% par Crithidia bombi (Zoomastigophorea, Trypanosomatina), 9,0\% par Nosema bombi (Microsporidea, Microsporida) et 3,6\% par Bombacarus buchneri (Acarina, Podapolipodidae). Le parasitisme a varié en fonction de l'espèce hôte pour tous les parasites et en fonction du sexe de l'hôte pour les conopidés, $C$ bombi et $N$ bombi (tableau I). Le parasitisme par les conopidés et $C$ bombi était plus fort chez les ouvrières que chez les mâles, tandis que $N$ 
bombi était plus fréquemment rencontré chez les mâles que chez les ouvrières. La probabilité pour des ouvrières infestées par $C$ bombi de porter des pelotes de pollen dans leurs corbicules était moindre que pour des ouvrières non infestées et celle d'avoir des ovaires développés, plus forte. En outre, les reines de printemps présentaient une prédominance plus faible de l'infestation par $C$ bombi que les ouvrières de l'été précédent (tableau II). Les différences de parasitisme par les conopidés en fonction de l'espèce et du sexe peuvent être dues à des différences spécifiques dans le degré de recouvrement temporel des effectifs de bourdons et de conopidés et à des comportements sexuels spécifiques. La faible infestation des mâles par $C$ bombi peut provenir du fait que ceux-ci passent moins de temps à l'intérieur des nids que les ouvrières et qu'ils ne participent pas aux soins au couvain. La différence de prédominance de $C$ bombi entre les ouvrières d'été et les reines du printemps suivant peut indiquer que certaines reines infestées ne passent pas l'hiver et/ou que certaines sont capables de perdre leur parasitisme au cours de l'hiver.

Bombus / Psithyrus / parasitisme / Crithidia / Nosema / Bombacarus / Conopidae

\section{Zusammenfassung - Vorkommen und} Auswirkungen von vier Parasiten in natürlichen Hummel-Populationen der Schweiz. Wir haben Häufigkeit und Verteilung von vier natürlichen Parasiten von Hummeln untersucht. Von 446 Hummeln (313 Arbeiterinnen und 133 Männchen), die im Juli und August 1988 auf Blüten gefangen wurden, waren $20.2 \%$ von Conopiden (Diptera, Conopidae), 35.7\% mit Crithidia bombi (Zoomastigophorea, Trypanosomatina), $9.0 \%$ mit Nosema bombi (Microsporea, Microsporidia) und $3.6 \%$ mit
Bombacarus buchneri (Acarina, Podalipodidae) befallen. Für alle Parasiten war die Parasitierung je nach der Art des Wirtes verschieden, aber nur für Conopiden, $C$ bombi und $N$ bombi auch nach dem Geschlecht des Wirtes unterschiedlich (Tabelle I). Die Parasitierung durch Conopiden und $C$ bombi war bei Arbeiterinnen höher als bei Männchen, für $N$ bombi war es umgekehrt. Von $C$ bombi befallene Arbeiterinnen trugen weniger häufig Pollen in ihren Körbchen und sie hatten öfter entwickelte Ovarien als unbefallene Arbeiterinnen. AuBerdem zeigten Frühjahrsköniginnen einen weit geringeren Befallsgrad mit $C$ bombi als Arbeiterinnen vom vorherigen Sommer (Tabelle II). Die Unterschiede im Befall der Arten und der beiden Geschlechter durch Conopiden könnte durch Artunterschiede bei der zeitlichen Überlappung der größten Häufigkeit von Conopiden und Hummeln und durch geschlechtsspezifisches Verhalten zu erklären sein. Der geringere Befall von $C$ bombi bei Männchen könnte dadurch entstehen, daß sich Männchen weniger im Nest aufhalten und daß sie sich nicht an der Brutpflege beteiligen. Der Unterschied in der Befallshäufigkeit von $C$ bombi bei Sommerarbeiterinnen und bei Königinnen im nächsten Frühjahr könnte dadurch entstehen, daß ein Teil der befallenen Königinnen den Winter nicht überlebt und/oder daß einige von ihnen in der Lage sind, die Infektion während des Winters wieder los zu werden.

Bombus / Psithyrus / Parasitismus / Crithidia / Nosema / Bombacarus / Conopidae

\section{REFERENCES}

Alford DV (1975) Bumblebees. Davis Poynter, London

Clark TB, Kellen WR, Lindegren JE, Smith TA (1964) The transmission of Crithidia fasciola- 
ta (Léger 1902) in Culiseta incidens (Thomson). J Protozool 11, 400-402

Cumber RA (1949a) Humble-bee parasites and commensals found within a thirty mile radius of London. Proc R Entomol Soc (Lond) 24, 119-127

Cumber RA (1949b) The biology of humblebees with special reference to the production of the worker caste. Trans $R$ Entomol Soc (Lond) 100, 1-45

Cumber RA (1953) Some aspects of the biology and ecology of humble-bees bearing upon the yields of red-clover seed in New Zealand. NZJ Sci Technol B 34, 227-240

Doorn A van (1989) Factors influencing dominance behaviour in queenless bumblebee workers (Bombus terrestris). Physiol Entomol $14,211-221$

Farrar CL (1947) Nosema losses in package bees as related to queen supersedure and honey yields. J Econ Entomol 40, 333-338

Fisher RM, Pomeroy N (1989) Incipient colony manipulation, Nosema incidence and colony productivity of the bumblebee Bombus terrestris (Hymenoptera: Apidae). J Kansas Entomol Soc 62, 581-589

Fyg W (1954) Über das Vorkommen von Flagellaten im Rectum der Honigbiene (Apis mellifica L). Mitt Schweiz Entomol Ges 27, 423428

Galen C, Plowright RC (1985) Contrasting movement patterns of nectar-collecting and pollen-collecting bumblebees (Bombus terricola) on fireweed (Chaemanerion angustifo(ia) inflorescences. Ecol Entomol 10, 9-17

Gorbunov PS (1987) Endoparasitic flagellates of the genus Crithidia (Trypanosomatidae, Zoomastigophorea) from alimentary canal of bumblebees. Zool Zh 66, 1775-1780 (in Russian)

Heinrich B (1979) Bumblebee Economics. Harvard University Press, Cambridge, MA

Jeffree EP, Allen MD (1956) The influence of colony size and of Nosema disease on the rate of population loss in honey bee colonies in winter. J Econ Entomol 49, 831-834

de Jonghe $R$ (1986) Crossing experiments with Bombus terrestris terrestris (Linnaeus, 1758) and Bombus terrestris xanthopus Kriechbaumer 1870 and some notes on diapause and nosemose (Hymenoptera, Apoidea). Phegea 14, 19-23

Langridge DF, McGhee RB (1967) Crithidia melificae $\mathbf{n}$ sp an acidophilic Trypanosomatid of the honey bee Apis mellifera. J Protozool 14, 485-487

Lipa JJ, Triggiani O (1980) Crithidia bombi sp n a flagellated parasite of a bumble-bee Bombus terrestris L. (Hymenoptera, Apidae). Acta Protozool 27, 287-290

MacFarlane RP, Pengelly DH (1974) Conopidae and Sarcophagidae (Diptera) as parasites of adult Bombinae (Hymenoptera) in Ontario. Proc Entomol Soc Ont 105, 55-59

Plowright RC, Jay SC (1966) Rearing bumblebee colonies in captivity. $J$ Apic Res 5,155 165

Pouvreau A (1974) Les ennemis des bourdons II. Organismes affectant les adultes. Apidologie 5, 39-62

Rinderer TE, Elliott KD (1977) Influence of nosematosis on the hoarding behavior of the honeybee. J Invertebr Pathol 30, 110.111

Röseler PF (1987) Größenpolymorphismus, Geschlechtsregulation und Stabilisierung der Kasten im Hummelvolk. In: Sozialpolymorphismus bei insekten (Schmid GH, ed) Wissenschaftliche Verlag $\mathrm{mbH}$, Stuttgart, 2nd edn, 298-335

SAS Institute (1985) SAS User's Guide: Statistics. SAS Institute, Cary, NC, 1985 edn

Schmid-Hempel P, Schmid-Hempel R (1988) Parasitic flies (Conopidae, Diptera) may be important stress factors for the ergonomics of their bumblebee hosts. Ecol Entomol 13, 469-472

Schmid-Hempel P, Schmid-Hempel R (1990) Endoparasitic larvae of conopid flies alter pollination behavior of bumblebees. Naturwissenschaften 77, 450-452

Schmid-Hempel P, Müller C, Schmid-Hempel R, Shykoff JA (1990) Incidence and ecological correlates of parasitism by conopid flies (Conopidae, Diptera) in populations of bumblebees. Insectes Soc 37, 14-30

Schmid-Hempel R, Schmid-Hempel P (1989) Superparasitism and larval competition in conopid flies (Dipts, Conopidae), parasitizing bumblebees (Hymenoptera, Apidae). Mitt Schweiz Entomol Ges 62, 279-289 
Showers RE, Jones FA, Moeller FE (1967) Cross-inoculation of the bumble bee Bombus fervidus with the microsporidian Nosema apis from the honey bee. J Econ Entomol 60, 774777

Shykoff JA, Schmid-Hempel P (1991) Parasites and the advantage of genetic variability within social insect colonies. Proc $R$ Soc Lond Ser $B 243,55-58$
Shykoff JA, Schmid-Hempel P (1991b) Genetic relatedness and eusociality: parasitemediated selection on the genetic composition of groups. Behav Ecol Sociobiol (in press)

Stammer HJ (1951) Eine neue Tracheenmilbe, Bombacarus buchnerin g, n sp (Acar, Podapolipodidae). Zool Anz 146, 137-150

Zar JH (1984) Biostatistical Analysis. Prentice Hall Inc, Engelwood Cliffs, NJ 